\title{
Redox stress proteins are involved in adaptation response of the hyperthermoacidophilic archaeon Sulfolobus solfataricus to nickel challenge
}

\author{
Anna M Salzano1, Ferdinando Febbraio², Tiziana Farias², \\ Giovanni P Cetrangolo ${ }^{2}$, Roberto Nucci ${ }^{2}$, Andrea Scaloni ${ }^{1}$ and \\ Giuseppe Manco*2
}

\begin{abstract}
Address: ${ }^{1}$ Laboratorio di Proteomica e Spettrometria di Massa, ISPAAM, Consiglio Nazionale delle Ricerche, 80147 Napoli, Italy and ${ }^{2}$ Istituto di Biochimica delle Proteine, Consiglio Nazionale delle Ricerche, Via Pietro Castellino 111, 80131 Naples, Italy

Email: Anna M Salzano - A.Salzano@iabbam.na.cnr.it; Ferdinando Febbraio - f.febbraio@ibp.cnr.it; Tiziana Farias - tifarias@tin.it; Giovanni P Cetrangolo - g.cetrangolo@ibp.cnr.it; Roberto Nucci - r.nucci@ibp.cnr.it; Andrea Scaloni - A.Scaloni@iabbam.na.cnr.it; Giuseppe Manco* - g.manco@ibp.cnr.it

* Corresponding author
\end{abstract}

Published: 12 August 2007

Microbial Cell Factories 2007, 6:25 doi:10.1186/1475-2859-6-25
Received: 7 June 2007

Accepted: 12 August 2007

This article is available from: http://www.microbialcellfactories.com/content/6/1/25

(C) 2007 Salzano et al; licensee BioMed Central Ltd.

This is an Open Access article distributed under the terms of the Creative Commons Attribution License (http://creativecommons.org/licenses/by/2.0), which permits unrestricted use, distribution, and reproduction in any medium, provided the original work is properly cited.

\begin{abstract}
Background: Exposure to nickel $(\mathrm{Ni})$ and its chemical derivatives has been associated with severe health effects in human. On the contrary, poor knowledge has been acquired on target physiological processes or molecular mechanisms of this metal in model organisms, including Bacteria and Archaea. In this study, we describe an analysis focused at identifying proteins involved in the recovery of the archaeon Sulfolobus solfataricus strain MT4 from Ni-induced stress.

Results: To this purpose, Sulfolobus solfataricus was grown in the presence of the highest nickel sulphate concentration still allowing cells to survive; crude extracts from treated and untreated cells were compared at the proteome level by using a bi-dimensional chromatography approach. We identified several proteins specifically repressed or induced as result of $\mathrm{Ni}$ treatment. Observed up-regulated proteins were largely endowed with the ability to trigger recovery from oxidative and osmotic stress in other biological systems. It is noteworthy that most of the proteins induced following $\mathrm{Ni}$ treatment perform similar functions and a few have eukaryal homologue counterparts.
\end{abstract}

Conclusion: These findings suggest a series of preferential gene expression pathways activated in adaptation response to metal challenge.

\section{Background}

Eight of the top 100 substances on the 2005 Agency for Toxic Substances and Disease Registry priority list are toxic metals, including arsenic, chromium, cadmium, and nickel [1]. Exposure to these metals is associated with a variety of adverse health effects to humans [2-4]; however, the mechanisms leading to the development of these diseases as well as the cellular pathways modified in response to these metals exposure just begin to be understood [4].

Heavy-metal resistance mechanisms in bacteria have been shown to exist in various species [5]. Metals, such as Cd, 
$\mathrm{Hg}$, and $\mathrm{Ag}$, have a chemical preference for thiol ligands [6], deactivating enzymes that contain thiols at their active sites. In addition, metals interact with other important trace elements in cells, inhibiting their normal physiological functions [6]. Metals, such as $\mathrm{Cu}, \mathrm{Fe}$, and $\mathrm{Mn}$, have direct oxidizing capacity, and other, such as $\mathrm{Ni}, \mathrm{Co}$, and $\mathrm{Zn}$, cause indirect oxidative stress through uncoupling of electron transport in both respiration and photosynthesis and depletion of glutathione (GSH), leading to the accumulation of reactive oxygen species (ROS). The intracellular generation of superoxide by $\mathrm{Cd}, \mathrm{Ni}$, and $\mathrm{Co}$ is toxic in Escherichia coli [7], and superoxide dismutase is involved in protection against this metal-induced oxidative stress [7].

Investigation of the biochemical and genetic metal homeostasis and resistance mechanisms of acidophilic microorganisms, particularly of the Archaea, is virtually in its infancy. The Archaea represent challenging yet environmentally relevant systems for an increased understanding of metal resistance and homeostasis [8]. As result of the elucidation of its genome sequence in 2001 [9], hyperthermoacidophilic crenarchaeon Sulfolobus solfataricus, which grows between 70 and $90^{\circ} \mathrm{C}$ and in a pH range of $2-4$ [10], is an attractive crenarchaeal model organism for functional genomic analysis. Since its isolation in the early 1980s, its preference for environments hostile to many other organisms made it an interesting source for novel thermostable enzymes. Out of the 2977 ORFs originally identified in the genome of $S$. solfataricus, 1941 genes still have no known function in TIGR's comprehensive microbial resource database [11]. Given the similarity with some pivotal eukaryal genes, the Sulfolobus craenarchaeon genus has been considered a simplified model for the analysis of complex topics not easily approachable in human [12]. In particular, the replication, recombination, repair, transcription and translation proteins are homologous to those of eukaryotes, despite the fact that the Archaea are prokaryotes. To fully exploit its potential, few proteomics investigations exploring gene products expressed within the cell have been reported [13-15]. However, only about $50 \%$ of the putative ORFs have been detected as really expressed in one case [14] and $10 \%$ in the second one [15]. Other proteomic studies on quantitative evaluation of protein expression changes for a defined set of genes are currently being carried out $[16,17]$.

In this study, we investigated the adaptation response of $S$. solfataricus to challenging environments by analyzing its changes in protein repertoire. We focused on perturbations generated by chemical toxic compounds, and particularly, heavy metals on cytosolic proteins. Given the particular significance of $\mathrm{Ni}$ on human health, the study of Ni effects in the model system S. solfataricus might shed some light on similar effects in human. This manuscript reports some Sulfolobus proteins that significantly changed their expression levels following cell exposure to $\mathrm{NiSO}_{4}$.

\section{Results and Discussion}

\section{Growth of S. solfataricus MT4 in nickel sulphate}

Small-scale growth experiments on $S$. solfataricus were performed to determine the highest concentration of chemical perturbing agent to be added, which maintained cells keep on growing. Six tubes were prepared each containing $3 \mathrm{~mL}$ of a $0.1 \mathrm{OD}_{600 \mathrm{~nm}}$ culture and concentrations of 0 , $50,100,200,400,800 \mu \mathrm{M} \mathrm{NiSO}_{4}$, respectively. Tubes were incubated to $80^{\circ} \mathrm{C}$, under shaking, for 19 and $48 \mathrm{~h}$ and then absorbance was read (Fig. 1). At concentrations of $\mathrm{NiSO}_{4}$ higher than $200 \mu \mathrm{M}$ cells did not grow; therefore, a $100 \mu \mathrm{M} \mathrm{NiSO}_{4}$ concentration was chosen for the large-scale experiment.

Starting from the preliminary experiment mentioned above, we scaled up to 1-liter experiment for proteomic analysis. As described in the experimental section, a $2 \mathrm{~L}$ cell culture was split in two halves; whereas one was incubated with $100 \mu \mathrm{M} \mathrm{NiSO}{ }_{4}$, at $80^{\circ} \mathrm{C}$, under shaking, the other did not received metal supplement and was taken as control growing under the same experimental conditions. Cells were centrifuged and broken by sonication. Solubilized proteins from both cultures were recovered as reported in the experimental section and compared by bidimensional chromatography [18].

\section{Protein analysis}

Samples of crude cellular extracts were separated by chromatofocusing in the range of $\mathrm{pH} 6-4$, as described in the experimental section. Fig. 2 shows a typical chromatogram obtained. Fractions from four identical runs were separately pooled for both different cultures; then, each pooled fraction was fractionated by RP-HPLC, as reported in the experimental section. A total of 9 chromatographic runs were performed. Chromatographic profile of the same fractions from Ni-treated and control culture were superimposed and compared; at this stage, it was already possible to observe some differences. In Fig. 3 it is shown a typical result corresponding to reverse-phase chromatograms of chromatofocusing fractions number 6, both from control and treated cells. As shown, there was a clear difference in the chromatographic profiles in the range 30-55 min. Fractions associated to major differences in control and treated runs were concentrated and analysed by $12 \%$ SDS-PAGE. We focused on fractions showing a clear appearance/disappearance of protein bands, thus choosing only qualitative criteria of selection from electrophoresis analysis. As an example, Fig. 4 shows the comparison between the RP-HPLC fractions eluted in the 3537 min range (Fig. 3) from treated and control culture. Bands of interest were excised and analysed by peptide 
Table I: Down/up-regulated proteins detected following challenge of $\mathrm{S}$. solfataricus with $100 \mu \mathrm{M} \mathrm{NiSO}{ }_{4}$.

\begin{tabular}{|c|c|}
\hline \multicolumn{2}{|l|}{ Down-regulated proteins } \\
\hline $\begin{array}{l}\text { NAD-dependent malic enzyme (malate } \\
\text { oxidoreductase) }\end{array}$ & SSO2869 \\
\hline Hypothetical protein & SSO 1388 \\
\hline $\begin{array}{l}\text { Carbon monoxide dehydrogenase. large chain } \\
\text { (cutA-6) }\end{array}$ & SSO2942 \\
\hline $\begin{array}{l}\text { Carbon monoxide dehydrogenase, small chain } \\
\text { (cutC-I) }\end{array}$ & SSO2433 \\
\hline Acetyl-coenzyme A synthetase & SSOI3I4 \\
\hline \multicolumn{2}{|l|}{ Up-regulated proteins } \\
\hline Putative peroxiredoxin & SSO2255 \\
\hline Hypothetical protein & SSO2253 \\
\hline Pyrodoxyn ethylene inducible & SSO0570 \\
\hline Hypothetical protein & SSOII52 \\
\hline Transcription regulator (exsB) related protein & SSO0016 \\
\hline Maltooligosyltrehalose synthase (treY) & SSO2095 \\
\hline NAD-specific glutamate dehydrogenase (gdhA-I) & SSOI457 \\
\hline NAD-specific glutamate dehydrogenase (gdhA-2) & SSO 1907 \\
\hline $\begin{array}{l}\text { Carbon monoxide dehydrogenase large chain (cutA- } \\
\text { I) }\end{array}$ & SSOI 209 \\
\hline Hypothetical protein & SSO0886 \\
\hline Hypothetical protein & SSO2190 \\
\hline
\end{tabular}

mass-fingerprint analysis to identify variable proteins. Differential expression data from SDS-PAGE/peptide mass fingerprint analysis were confirmed by shotgun analysis of protein samples [19].

By using this methodology, we identified different proteins significantly varying their abundance in the treated versus the control sample (manuscript in preparation). Table 1 shows selected proteins detected only in the control or in the Ni-treated samples. Five proteins were detected only in the non-treated sample, whereas eleven proteins were detected only in the nickel-treated sample. Proteins disappearing after $\mathrm{Ni}$ treatment were a NADdependent malic enzyme involved in energy uptake, a group of four hypothetical proteins of unknown function made up of three CO dehydrogenase subunits (large chain cutA- 6 and small chain cutC-1) and acetyl-coenzyme A synthetase. Carbon monoxide dehydrogenase/acetyl-CoA synthase (CODH/ACS) complex in M. thermophila is part of a five-subunit complex consisting of $\alpha, \beta, \gamma, \delta$, and $\varepsilon$ subunits [20]. The multienzyme complex catalyzes the reversible oxidation of $\mathrm{CO}$ to $\mathrm{CO} 2$, transfer of the methyl group of acetyl-CoA to tetrahydromethanopterin (H4MPT), and acetyl-CoA synthesis from CO, CoA, and methyl-H4MPT. The $\alpha$ and $\varepsilon$ subunits are required for CO oxidation. The $\gamma$ and $\delta$ subunits constitute a corrinoid iron-sulfur protein that is involved in the trans-methyla- tion reaction. Isolated $\beta$ subunit contains significant amounts of nickel. The $\beta$ subunit harbors cluster $A$, a $\mathrm{NiFeS}$ cluster, which is the active site of acetyl-CoA cleavage and assembly. Although the $\beta$ subunit is necessary, it is not sufficient for acetyl-CoA synthesis; interactions between the $\mathrm{CODH}$ and the ACS subunits are required for cleavage or synthesis of the C-C bond of acetyl-CoA. These interactions include intra-molecular electron transfer reactions between the CODH and ACS subunits [21]. The role of this complex in the adaptation to metal stress conditions is currently unknown.

On the contrary, several proteins of particular interest occurred in the group of up-regulated proteins (Table 1). In particular, the first one is the protein Bcp 3 corresponding to $S$. solfataricus ORF SSO2255, which is annotated as putative peroxiredoxin (Prx). Four paralogous ORFs, with similarity to Prxs and annotated as Bcp1-4 (SSO2071, SSO2121, SSO2255 and SSO2613, respectively), are present in the S. solfataricus genome [9]. S. solfataricus Bcp bearing the greatest similarity to other Prxs in the GenBank Database is Bcp2, which encodes for a protein of 215 amino acids. Bcp2 reveals $40 \%$ of identity with 1-Cys Human PRDX6. Analysis in S. solfataricus of this gene and the protein encoded by it has been recently reported [22]. Its role in oxidative stress was investigated by transcriptional analysis of RNA isolated from cultures stressed by various oxidative agents. Its specific involvement was confirmed by a considerable increase of the Bcp2 transcript following induction by $\mathrm{H}_{2} \mathrm{O}_{2}$. Using dithiothreitol as an electron donor, this enzyme acts as a catalyst in $\mathrm{H}_{2} \mathrm{O}_{2}$ reduction and protects plasmid DNA from nicking by the metal-catalysed oxidation system. Western blot analysis revealed that the Bcp2 expression was induced as a cellular

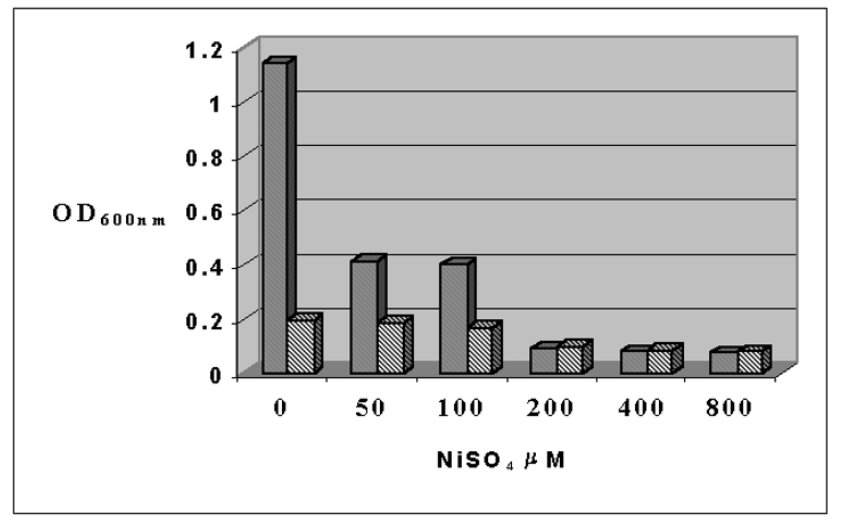

\section{Figure I}

Effect of Ni addition on the growth of Sulfolobus solfataricus. Sulfolobus solfataricus was grown aerobically in a rotary shaker, at $80^{\circ} \mathrm{C}$ for 19 (gray columns) or $48 \mathrm{~h}$ (striped columns), in the presence of $0,50,100,200,400$ and $800 \mu \mathrm{M}$ nickel sulphate. Cell reading was performed at $600 \mathrm{~nm}$. 
adaptation in response to the addition of exogenous stressors. The results obtained indicate that Bcp2 plays an important role in the peroxide-scavenging system in $S$. solfataricus [22] and it is expected that the other genes have a similar role. No biochemical data are available on the other three bacterial Prx forms. In P. horikoshi it has been reported that $\mathrm{Bcp} 2$ protein is induced as well following oxidative stress [23]. The observation that Bcp3 appears after nickel treatment could be interpreted as due to a similar specific induction, thus supporting the idea that is involved in the recovery from metal-induced stressing conditions. The genome location of the corresponding gene is shown in Fig. 5A.

A second protein worth of noting is the hypothetical ORF SSO2253 (Table 1), which is located at the same locus and on the same (lagging) strand of Bcp3, but head of a cluster of four genes (see Fig. 5A) containing Rad30/Mre11 and Rad50 homologues involved in DNA recombination and repair in Eukarya [24]. This operon in Archaea contains two additional conserved ORFs. The first one has recently been reported to code for a nuclease, suggesting that the operon is linked to double strand break repair and recombination in Archaea [25]. The second one codes for a novel $60-\mathrm{kDa}$ protein (termed MlaA/HerA) with a bimodal helicase activity [26,27]. MlaA/HerA is fused with Mre11 in $M$. thermoautotrophicus, suggesting that MlaA is functionally linked to the Mre11 complex [27]. The conservation of this archaeal operon suggests that these four proteins could participate in the same repair/recombination pathway, but no evidences have been provided of such a role in vivo. Till now no clues are available for a role of SSO2253. The gene is conserved at the same position also in S. acidocaldarius and S. tokodai, whereas is on the opposite strand in P. torridus. The stop codon for SSO2253 is at $87 \mathrm{nt}$ from the ATG starting codon of SSO2251 (MlaA/HerA). A sequence analysis with the program PredictProtein (see Methods), allowed predicting for this protein a ferritin-like fold and PSI-Blast predicted weak similarity to some archaeal and bacterial rubrerytrins. However, no similarity was detected with a second Sulfolobus rubrerytrin, namely SSO2642. Accordingly, our results suggest the possibility of a coordinate action of all the proteins at this locus in oxidative stress recovery.

Induced expression of putative "ethylene-inducible" gene SSO0570 was also observed; its protein product belongs to the Sor/SNZ family, involved in the biosynthesis of vitamin B6 [28]. Pyridoxine, pyridoxal, and pyridoxamine are collectively called vitamin B6. Being a cofactor for many enzymatic reactions, especially those involved in amino acid metabolism, vitamin B6 is required for all organisms [29]. Two distinctive de novo pyridoxine biosynthesis pathways have been identified. One well-characterized pathway exists in some eubacteria such as
Escherichia coli. In this pathway, pyridoxine is synthesized from 1-deoxy-D-xylulose-5-phosphate and 4-phosphohydroxy-L-threonine through pyridoxine synthase proteins Pdx2A and Pdx2J [30,31]. The second pathway has just begun to be elucidated in fungi, archaeabacteria, and some eubacteria. In these organisms, pyridoxine may be synthesized from glutamine and ribose 5-phosphate or ribulose 5-phosphate through two families of conserved proteins: the singlet oxygen resistance (SOR)/snooze (SNZ) family and the SNZ proximal open reading frame (SNO) [32]. A homologous gene found in Cercospora fungi is SOR1, a gene with demonstrated activity against singlet oxygen [33]. Preponderance of work on reactive oxygen species has focused on reduced forms of oxygen, hydrogen peroxide $\left(\mathrm{H}_{2} \mathrm{O}_{2}\right)$, radicals superoxide $\left(\mathrm{O}_{2}{ }^{\bullet 2}\right)$ and the hydroxyl radical $(\mathrm{OH} \bullet)$; contrarily, singlet oxygen $\left({ }^{1} \mathrm{O}_{2}\right)$, a highly reactive but non-radical species of active oxygen, has received relatively less attention. ${ }^{1} \mathrm{O}_{2}$ is primarily generated via photosensitization [34]. Photosensitizers and photoactizers are a diverse and ubiquitous group of compounds and natural products synthesized by plants, microorganisms, and protozoans. Singlet oxygen reacts rapidly with biomolecules such as lipids, proteins, and nucleic acids and shows almost universal toxicity to cells. Cercospora fungi use production of cercosporin, a photosenthitizer, to parasitize plants [35]. Despite the prevalence of photosensitizers, little is known about effective cellular defences against them and the ${ }^{1} \mathrm{O}_{2}$ they generate upon illumination. Defenses effective against radical and reduced oxygen species (e.g., superoxide dismutase, catalase, peroxidases) are not effective against ${ }^{1} \mathrm{O}_{2}$. Vitamin $\mathrm{B} 6$ has been demonstrated to be able to quench superoxide and singlet oxygen [36,37]. The discovery of the involvement of the biosynthetic route to vitamin B6 in the archaeon $S$. solfataricus as mean for recovery from $\mathrm{Ni}$ induced oxidative stress could $i$ ) suggest production of ${ }^{1} \mathrm{O}_{2}$ under such conditions, ii) confirm its role as bioscavenger for ${ }^{1} \mathrm{O}_{2}$ and $\mathrm{O}_{2} \cdot 2$ [36,37] and iii) suggest this mechanism as very ancient, being $S$. solfataricus a craenarcheon. However, although there are several papers showing that nickel alone or in combination with other compounds induces ROS formation (comprising singlet oxygen production) and a few supporting the notion of singlet oxygen production in cells [38,39], Ni transition metalchelates are good singlet oxygen quenchers. The point is if nickel induces per se singlet oxygen or if this is a secondary effect. The possibility of a secondary effect could not be discharged. Singlet oxygen for example can be produced by a dismutation reaction from superoxide ions or a reaction between hydrogen peroxide and superoxide ions in acidic environment.

Quite interestingly, in the genome location (Fig. 5B) nearby the gene is present ORF SSO0571 coding for a predicted glutamine amidotransferase involved in pyrodoxyn 


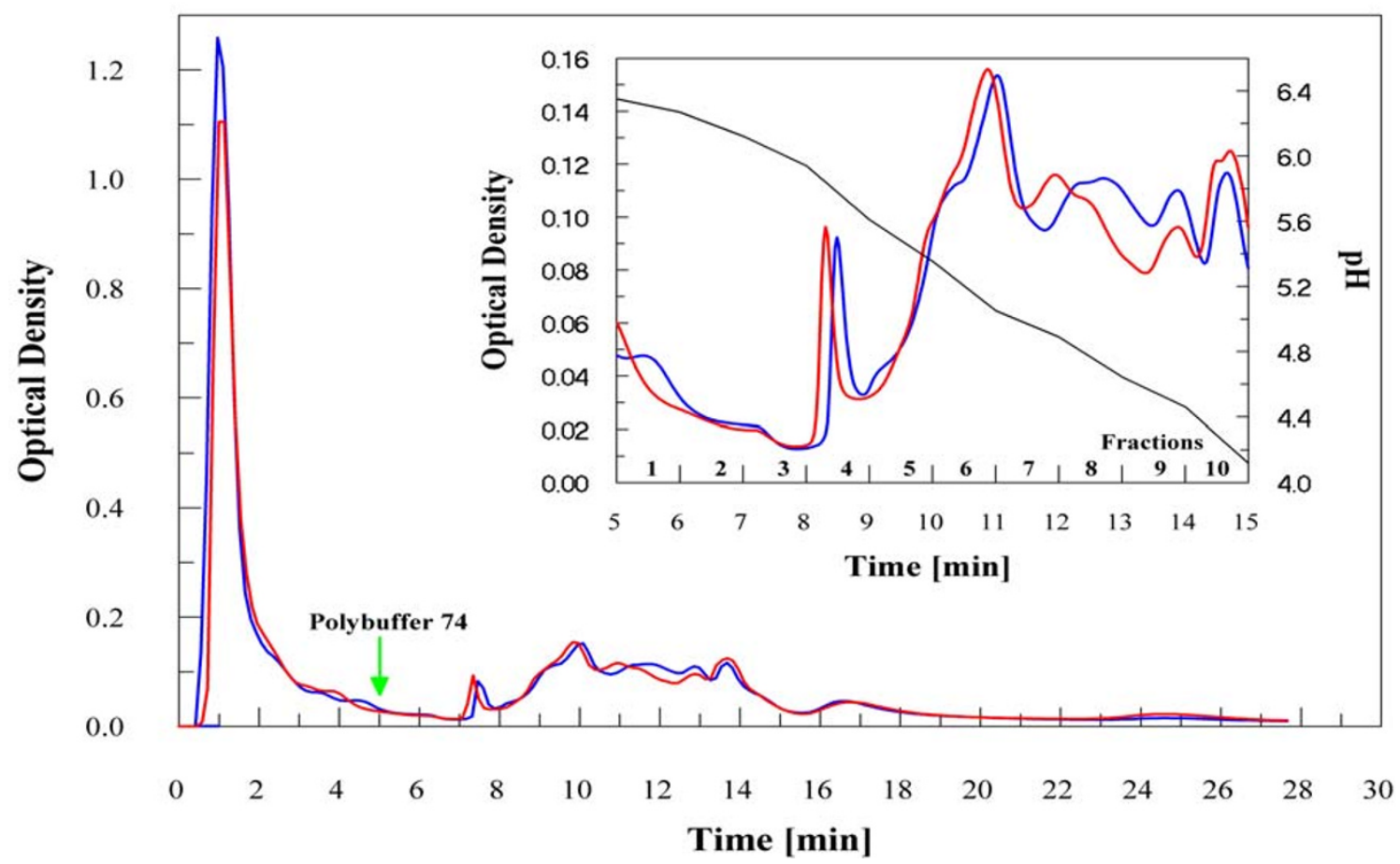

Figure 2

Chromatofocusing fractionation. Profile of the chromatofocusing in the range $\mathrm{pH} 6-4$ of the protein extract ( $10 \mathrm{mg} / \mathrm{mL})$ from control [blue line] and cells perturbed with $100 \mu \mathrm{M}$ nickel sulphate [red line]. A green arrow at 5 min indicates start of elution with polybuffer 74. In the insert is shown the zoomed region of the chromatogram from 5 to 15 min corresponding to the $\mathrm{pH}$ elution and fractions analysed by RP-HPLC.

biosynthesis, which has been found co-eluting with "ethylene-inducible protein" SSO0570 in the Ni-treated sample (data not shown). In conclusion, ORFs SSO0570 and SSO0571 represent the archaeal synthase/glutaminase bifunctional enzyme involved in de novo vitamin $\mathrm{B} 6$ biosynthesis. The occurrence of both subunits in the same chromatofocusing fraction may suggest a possible physical association; actually, physical interaction between SNZ1 and SNO1 has been already reported in yeast [40].

Other two proteins, namely ORF SSO0866 and ORF SSO2190, were found induced following Ni stress. These proteins are annotated as hypothetical proteins because only a very weak similarity to a molecular chaperon (COG0443) and a dithiol-disulfide isomerase involved in polyketide biosynthesis (COG2761), respectively, was detected with a BLAST search. Their involvement in response to redox stress could be only hypothesized, as already observed in other organisms for this class of enzymes. These hypothetical proteins were found in a locus rich in proteins of unknown function.

The protein SSO1152 has similarity with the peptidase U62 of the PmbA/TldD family. This protein, which has been originally described as a gyrase modulator in E. coli [41], is a Zn-dependent peptidase [42]. The finding of this protein only in the Ni-treated sample is particularly significant in view of the observation that the unique gyrase reported from $S$. solfataricus, namely reverse gyrase, was detected in both samples subjected to shotgun sequencing (data not shown). This could suggest a physical association between the putative peptidase U62 and reverse gyrase in only the Ni-treated sample. Recently, it has been reported that reverse gyrase activity and immuno-related material decreases in Sulfolobus cells treated by MMS [43]; this decrease has been attributed to a metal-dependent protease. The speculation that the putative peptidase U62 


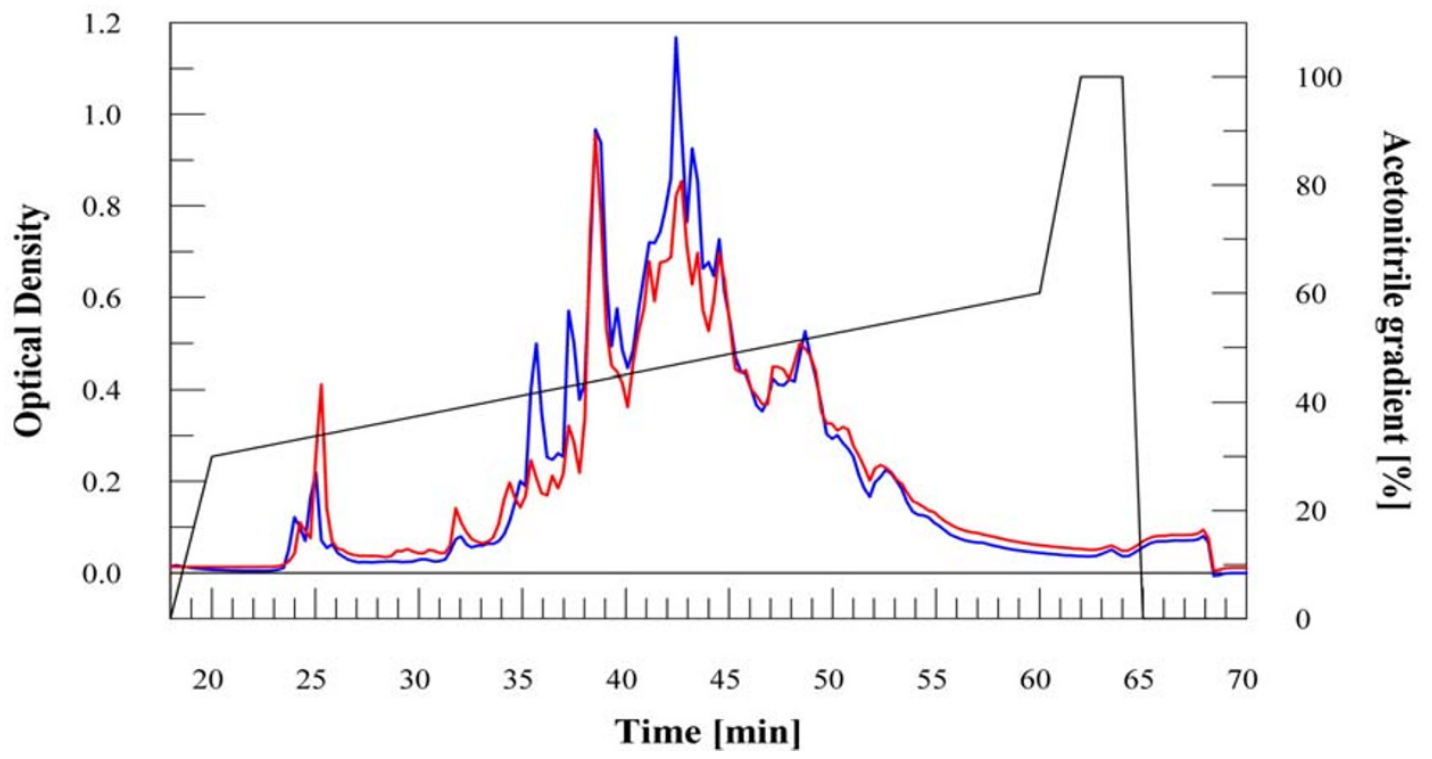

Figure 3

RP-HPLC fractionation. RP-HPLC profile of the sample $\mathrm{n} .6$ from control [blue line] and cells perturbed with $100 \mu \mathrm{M}$ nickel sulphate [red line].

might bind reverse gyrase and fulfill this role could be a work hypothesis for further experimentation.

The protein SSO0016 encodes for a transcription regulator $(\operatorname{exs} B)$ related protein. This family includes putative transcriptional regulators from Bacteria and Archaea. In $R$. meliloti, a species in which the exo genes make succinoglycan, a symbiotically important exopolysaccharide, exs $B$ is located nearby and affects succinoglycan levels [44]. In $A$. viscosus, the homologous gene is designated ALU1 and is associated with an aluminium tolerance phenotype. The function is unknown [45]. In Sulfolobus SSO0016 is adjacent to a putative permease (SSO0015) and to a putative membrane protein (SSO0014), both of unknown function.

Threalose is a well-known sugar, which serves as carbon source but is also involved in adaptation to physical and chemical stresses in several organisms. In Anabaena 7120 cells, it has been reported induction of enzyme maltooligosyltrehalose synthase (MTSase) following osmotic stress [46]. Santos group [47] reported that the level of OtsA (a gene involved in threalose synthesis) was enhanced (approximately twofold) by osmotic, oxidative and acid stress, whereas the level of TreS (threalose degradation) remained constant, or decreased, under identical stress conditions. Therefore, the OtsA-OtsB pathway plays an important role in the synthesis of trehalose in response to stress. Furthermore, in the papers of Wright and Dratz, cited above [14,15], the protein TreY was identified in both cases, although growth conditions were the same as reported by us. The up-regulation of this enzyme in the Sulfolobus Ni-treated sample is in agreement with the above report. The structure reported from Deinococcus radiodurans suggests the presence of metals at the active site [48].

The two NAD-specific glutamate dehydrogenases have also been found in Ni-treated cells. The increase/induction of these enzymes could be related to recovery from oxidative stress, as observed for the homologous enzyme from plants [49], but the exact pathway of how this happens in Archaea remains to be determined.

Nickel ion is specifically incorporated into Ni-dependent enzymes, often via complex assembly processes requiring accessory proteins and additional non-protein components, in some cases accompanied by nucleotide triphosphate hydrolysis. To date, nine Ni-containing enzymes are known: urease, NiFe-hydrogenase, carbon monoxide dehydrogenase, acetyl-CoA decarbonylase/synthase, methyl coenzyme $M$ reductase, certain superoxide dis- 


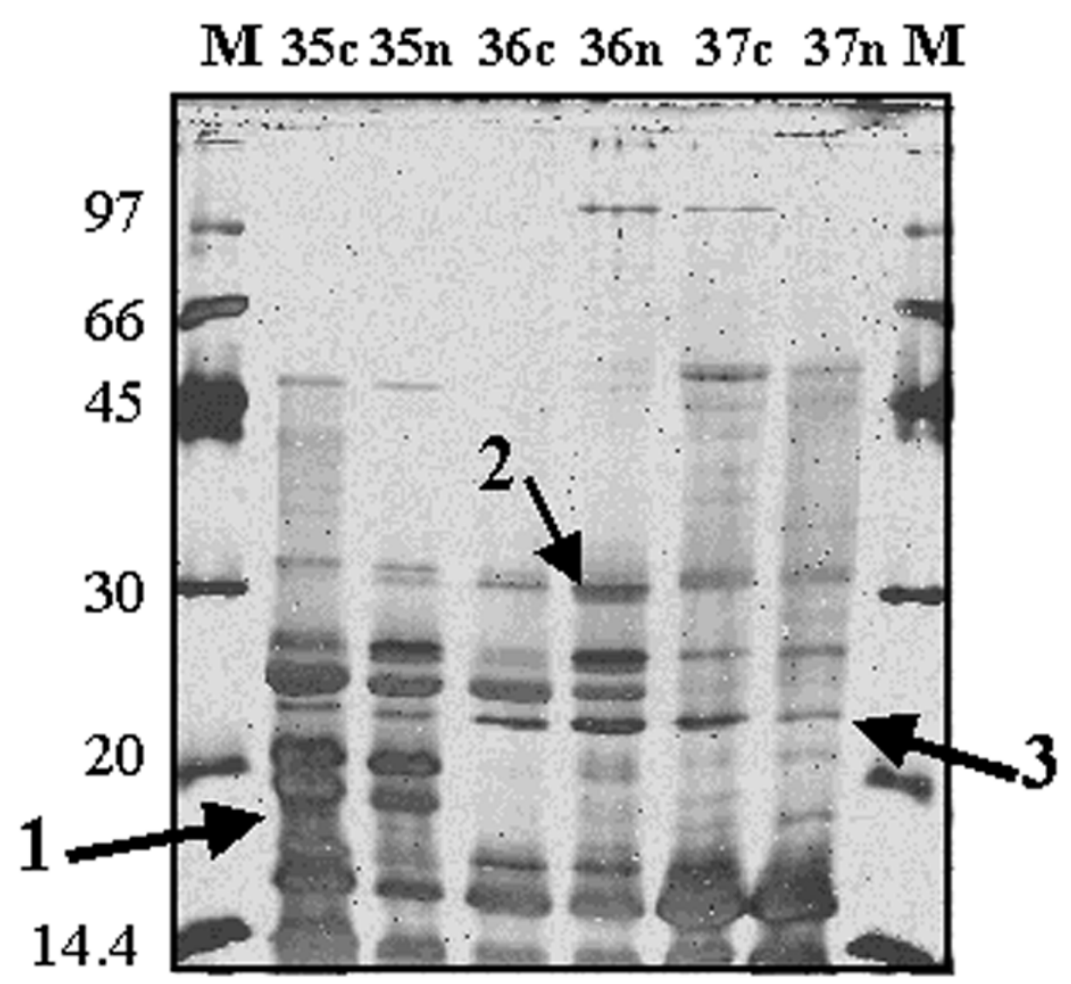

\section{Figure 4}

SDS-PAGE of specific RP-HPLC fractions. Lanes I and 7, protein markers; lanes 2-6, fraction 35-37 from control (c) and Ni-treated (n) samples. Fractions from RP-HPLC were desiccated and one third was loaded on the gels. Bands I, 2 and 3 were identified as protein SSO2433, SSO2190 and SSO0886, respectively.

mutases, some glyoxylases, aci-reductone dioxygenase, and methylenediurease. Seven of these enzymes have been structurally characterized, revealing distinct metallocenter environments in each case [50]. Among these enzymes, three kinds of CO dehydrogenases were found in this analysis. In particular, SSO2942 and SSO2433 appeared only in the control; SSO1209 which was detected only in the Ni-treated cells (Table 1). All the proteins are annotated as homologs of Cox/Cut proteins [51], but their genome location in $S$. solfataricus is not the same. Since in some cases, specific CO dehydrogenases have been implicated in oxidative stress response [52], the selective presence of these subunits in $S$. solfataricus control and treated samples could be related to a switch from energy up-take to oxidative stress recovery.

\section{Conclusion}

In this study, we described a proteomics investigation based on bi-dimensional chromatography focused to understand the mechanisms that underlay the recovery from Ni-induced stress in S. solfataricus. We identified several proteins that specifically were associated with the $\mathrm{Ni}$ treated sample, providing evidences on its specific induction. Most of these proteins are largely endowed with the ability to trigger recovery from oxidative and osmotic stress in other systems. However, our findings suggest that other preferential gene expression pathways are activated in adaptation response to metal challenge. Apart from proteins with an on/off response discussed here, there is a lot that just change their expression level (data not shown). Currently, we are involved in the quantitative evaluation of these proteins to define a comprehensive picture of nucleotide sites in the promoter region of genes 


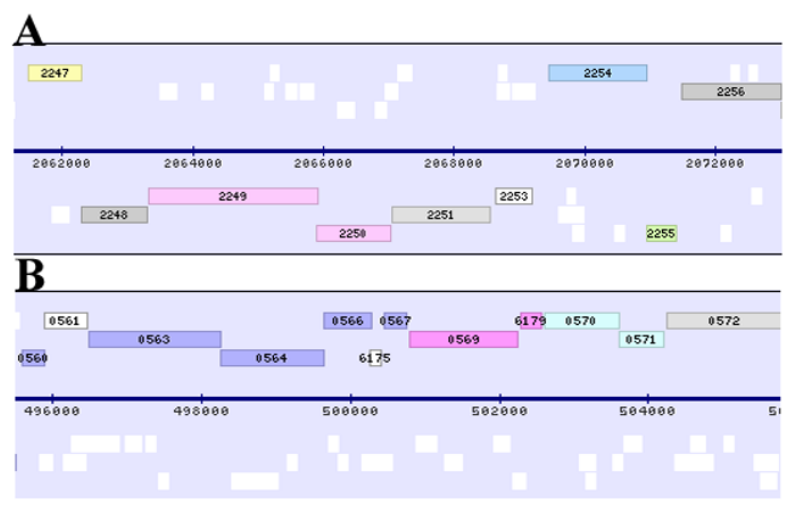

Figure 5

Genome location of selected identified ORFs. Panel

A. Genome location of ORF SSO2255 (green) and SSO2253 (white) in front of a cluster of genes suggested to be involved in DNA repair/recombination (Rad32/Mre I I: SSO2250; Rad50: SSO2249; NurA: SSO2248; MlaA/HerA: SSO225I). Panel B. Genome location of ORFs SSO0570 and SSO057I (green). Pictures were adapted from ref. [68].

whose expression varied as result of $\mathrm{Ni}$-sensitive regulators action. These results will provide a better comprehension of biochemical processes related to metal stress resistance in $S$. solfataricus, allowing defining the molecular bases of adaptation response.

\section{Methods}

\section{Materials}

Gelrite gellan gum, D-glucose, trypsin, $\alpha$-cyano-4-hydroxycinnamic acid, Coomassie Brilliant Blue R-250 and salts were from Sigma. Yeast extract and casamino acids were obtained from Difco Laboratories. Polybuffer 74 was purchased from Pharmacia; molecular mass protein markers were from BioRad. All other reagents and HPLC-grade solvents were from Fluka.

\section{Growth of the archaeon Sulfolobus solfataricus strain MT4}

Fresh S. solfataricus MT4 cells were prepared starting from cell stabs stored at $-80^{\circ} \mathrm{C}$, which were streaked on plates containing $0.8 \%$ Gelrite gellan gum medium supplemented by $0.1 \%$ D-glucose and incubated at $80^{\circ} \mathrm{C}$, for 3 days. A pre-culture was prepared by incubating $70 \mu \mathrm{L}$ of spots with $100 \mathrm{~mL}$ of medium, $\mathrm{pH} 3.7-3.8$, containing 1 $\mathrm{g} / \mathrm{L}$ yeast extract, $1 \mathrm{~g} / \mathrm{L}$ casamino acids, $2.5 \mathrm{~g} / \mathrm{L}\left(\mathrm{NH}_{4}\right)_{2} \mathrm{SO}_{4}$ $3.1 \mathrm{~g} / \mathrm{L} \quad \mathrm{KH}_{2} \mathrm{PO}_{4}, 20 \mathrm{mg} / \mathrm{L} \quad \mathrm{MgSO}_{4} \cdot 7 \mathrm{H}_{2} \mathrm{O}, 25 \mathrm{mg} / \mathrm{L}$ $\mathrm{CaCl}_{2} \cdot 2 \mathrm{H}_{2} \mathrm{O}, \quad 1.8 \mathrm{mg} / \mathrm{L} \quad \mathrm{MnCl}_{2} \cdot 4 \mathrm{H}_{2} \mathrm{O}, 4.5 \mathrm{mg} / \mathrm{L}$ $\mathrm{Na}_{2} \mathrm{~B}_{4} \mathrm{O}_{7} \cdot 10 \mathrm{H}_{2} \mathrm{O}, 0.22 \mathrm{mg} / \mathrm{L} \mathrm{ZnSO}_{4} \cdot 7 \mathrm{H}_{2} \mathrm{O}, 0.05 \mathrm{mg} / \mathrm{L}$ $\mathrm{CuCl}_{2} \cdot 2 \mathrm{H}_{2} \mathrm{O}, 0.03 \mathrm{mg} / \mathrm{L} \mathrm{Na} \mathrm{NaO}_{4} \cdot 2 \mathrm{H}_{2} \mathrm{O}, 0.03 \mathrm{mg} / \mathrm{L}$ $\mathrm{VaSO}_{4} \cdot 2 \mathrm{H}_{2} \mathrm{O}, 0.01 \mathrm{mg} / \mathrm{L} \mathrm{CoSO}_{4} \cdot 7 \mathrm{H}_{2} \mathrm{O}$ and $0.1 \%$ D-glucose. Cells were grown aerobically in a rotary shaker, at $80^{\circ} \mathrm{C}$, for 19 or $48 \mathrm{~h}$; growth was monitored by measuring the turbidity at $600 \mathrm{~nm}$. On the other hand, a $2 \mathrm{~L}$ cell culture was grown under the same conditions and split in two halves at starting $\mathrm{OD}_{600 \mathrm{~nm}}=0.1$; whereas one received $100 \mu \mathrm{M} \mathrm{NiSO}$ (final concentration), the other was taken as control. Cultures were incubated at $80^{\circ} \mathrm{C}$ under shaking for $19 \mathrm{~h}$. Cells were recovered by centrifugation at $6000 \mathrm{~g}$, for $10 \mathrm{~min}$. About $1.5 \mathrm{~g}$ of cells were obtained for each culture, which were re-dissolved in 3.5 vol of $20 \mathrm{mM}$ Tris- $\mathrm{HCl}$ buffer $\mathrm{pH} 8$, containing $1 \mathrm{mM}$ PMSF, 0.5 mM EDTA, 5 mM DTT. Cells were broken by sonication (Braun). The cellular debris was removed by centrifugation at $20200 \mathrm{~g}$, for $15 \mathrm{~min}$, and soluble proteins were recovered. Protein concentration of the supernatant was determined using the Bradford Protein Assay (Sigma). Supernatants were stored at $-80^{\circ} \mathrm{C}$ until used. Proteomic experiments were performed in triplicate using each time protein extracts from three different bacterial cultures.

\section{Bi-dimensional chromatography}

Aliquots of protein extracts $(10 \mathrm{mg} / \mathrm{mL})$ from S. solfataricus cells grown under standard conditions and in Ni-supplemented medium were analysed by chromatofocusing on a FPLC AKTA apparatus (Pharmacia), using a column Mono P HR 5/5 (Pharmacia) equilibrated in $25 \mathrm{mM}$ BisTris buffer, $\mathrm{pH}$ 6.3. Proteins were eluted in the $\mathrm{pH}$ ranges 6-4 by using 1:10 v/v diluted Polybuffer 74 pH 4.0 (Pharmacia), at flow rate of $1 \mathrm{~mL} / \mathrm{min}$. Nine eluted fractions ( 3 $\mathrm{ml}$ each) were collected for control and Ni-perturbed cell extracts. After appropriate volume reduction, fractions were analysed by RP-HPLC on a Dionex P580 apparatus, equipped with a PDA-100 photodiode Array detector, using a Chrompack Vydac C4 column (250 × $4.6 \mathrm{~mm})$, equilibrated in $0.1 \%$ TFA. Proteins were eluted in $70 \mathrm{~min}$ using non-linear gradient of $0-100 \%$ acetonitrile in $0.08 \%$ TFA, at a flow rate of $1 \mathrm{~mL} / \mathrm{min}$.

\section{Electrophoresis}

One-dimensional SDS-polyacrylamide gel electrophoresis was performed on the BioRad Mini-Protean II system $(7 \times$ $10 \mathrm{~cm}$ ) as described by Laemmli [53]. Fractions from RPHPLC were evaporated with a Savant and re-suspended in $30 \mu \mathrm{l}$ of loading buffer [54]. Ten $\mu$ l were loaded onto $12 \%$ acrylamide gels ( $1.5 \mathrm{~mm}$ thick), which were stained with 0.2 \% Coomassie Brillant Blue G250 or silver nitrate [55].

\section{Mass spectrometry}

Bands from SDS-PAGE were excised from the gel, Salkylated and digested with trypsin as previously reported [56]. Peptide digests were desalted using $\mu$ ZipTipC18 pipette tips (Millipore, USA) and loaded on the MALDI target together with CHCA as matrix, using the dried droplet technique. Samples were analysed with a Voyager-DE PRO spectrometer (Applera, USA). Mass spectra for PMF 
experiments were acquired in reflectron mode; internal mass calibration was performed with peptides from trypsin autoproteolysis. Spectra were elaborated using the DataExplorer 5.1 software (Applera, USA) and Mascot software (Matrix Science, UK) [57] was used to identify spots from a NCBI non-redundant database. Candidates with program scores $>79$ were further evaluated by the comparison with Mr experimental values obtained from SDS-PAGE. Eventual occurrence of protein mixtures was ascertained by sequential searches for additional protein components using unmatched peptide masses.

RP-HPLC fractions showing differences in SDS-PAGE were also analyzed by a shotgun proteomic approach. In this case, fractions before and after fraction of interest were also analyzed in comparison. Protein mixtures were digested with $5 \mathrm{ng}$ of trypsin in $50 \mathrm{mM}$ ammonium bicarbonate, $\mathrm{pH}$ 8. Resulting peptide mixtures were analysed by $\mu$ LC-ESI-IT-MS/MS using a LCQ Deca Xp Plus mass spectrometer (ThermoFinnigan, USA) equipped with an electrospray source connected to a Phoenix 40 pump (ThermoFinnigan, USA). Peptide mixtures were separated on a capillary ThermoHypersil-Keystone Aquasil C18 Kappa column $(100 \times 0.32 \mathrm{~mm}, 5 \mu \mathrm{m})$ (Hemel Hempstead, UK) using a linear gradient from $10 \%$ to $60 \%$ of acetonitrile in $0.1 \%$ formic acid, over $60 \mathrm{~min}$, at flow rate of $5 \mu \mathrm{l} / \mathrm{min}$. Spectra were acquired in the range $\mathrm{m} / \mathrm{z} 200-$ 2000. Three injections were analyzed for each sample. Acquisition was controlled by a data-dependent product ion scanning procedure over the three most abundant ions, enabling dynamic exclusion (repeat count 2 and exclusion duration $3 \mathrm{~min}$ ). The mass isolation window and collision energy were set to $\mathrm{m} / \mathrm{z} 3$ and $35 \%$, respectively. Data were elaborated using the BioWorks 3.1 software provided by the manufacturer. Sequest algorithm [58] was used to identify proteins $\mu$ LC-ESI-IT-MS/MS experiments. Proteins were identified by comparison of tryptic peptide product ion mass spectra against those generated from a database [59] containing the traduced $S$. solfataricus P2 sequence [9] from, together with trypsin and keratins. Strain MT4 has been reported very similar to strain P2 based on criteria of genomic homology, physiological properties [60-62] and differences in specific genes $[63,64]$. Sequest parameters included selection of trypsin with up to 2 missed cleavage sites and dynamic mass modification associated to Met oxidation. Identified proteins were ranked in ascending order according to consensus scores and false positive identifications minimized by filtration against 4 of the following criteria: Xcorr $>2, \Delta \mathrm{Cn}$ $>0.2$, Sp $>400$, rsp $<5$, ions $>30 \%$ [65]. Where appropriate, protein identifications were checked manually to provide for a false positive rate of $<1 \%$ using Xcorr and $\Delta \mathrm{Cn}$ values described and validated elsewhere [66]. In the case of 1-DE bands, identified proteins were further evaluated by the comparison with Mr experimental values. In both cases, reproducibility and reliability of the results was subjected to the following criteria: i) proteins with more than 2 peptides were considered as reliable proteins, ii) single peptide protein identifications were considered reliable if they were found repeated in the same fraction number of other injections [19]. Differently expressed components were identified as proteins that were always present/ absent in a specific RP-HPLC fraction obtained from cells grown in a certain medium, which were always found as absent/present in the corresponding RP-HPLC fraction obtained from cells grown under different experimental conditions.

\section{Sequences analysis}

Sequences were analysed with program PredictProtein [67] or tools available under Sulfolobus solfataricus P2 web site [68].

\section{Competing interests}

The author(s) declare that they have no competing interests.

\section{Authors' contributions}

AMS performed mass spectrometry experiments. FF participated in the design of the study and helped in bidimensional chromatography and analysis of results. TF carried out bi-dimensional chromatography and bibliographic research. GC participated in bi-dimensional chromatography. RN participated in the design of the study. AS directed the mass spectrometry experiments, helped in writing the paper. GM Conceived the study, analysed and interpreted the results, drafted the paper. All Authors read and approved the final manuscript.

\section{Acknowledgements}

This study was supported from the MIUR-FIRB project RBAU0IPRLA "Studio della risposta fisiologica dell'archeobatterio ipertermofilo $S$. solfataricus alle perturbazioni chimico-fisiche. Comprensione delle vie metaboliche alle condizioni estreme".

\section{References}

I. Agency for Toxic Substances and Disease Registry priority list [http://www.atsdr.cdc.gov/]

2. Lee $Y \bar{W}$, Klein CB, Kargacin B, Salnikow K, Kitahara J, Dowjat K, Zhitkovich A, Christie NT, Costa M: Carcinogenic nickel silences gene-expression by chromatin condensation and DNA methylation - a new model for epigenetic carcinogens. Mol Cell Biol 1995, 15:2547-2557.

3. Barceloux DG: Nickel. J Toxicol Clin Toxicol 1999, 37:239-258.

4. Valko M, Rhodes CJ, Moncol J, Izakovic M, Mazur M: Free radicals, metals and antioxidants in oxidative stress-induced cancer. Chemico-Biological Interactions 2006, 160:1-40.

5. Nies DH: Microbial heavy-metal resistance. Appl Microbiol Biotechnol 1999, 5 I:730-750.

6. Hultberg B, Andersson A, Isaksson A: Copper ions differ from other thiol reactive metal ions in their effects on the concentration and redox status of thiols in HeLa cell cultures. Toxicology 1997, I I 7:89-97.

7. Geslin C, Llanos J, Prieur D, Jeanthon C: The manganese and iron superoxide dismutases protect Escherichia coli from heavy metal toxicity. Res Microbiol 200I, I 52:90I-905. 
8. Dopson M, Baker-Austin C, Koppineedi PR, Bond PL: Growth in sulfidic mineral environments: metal resistance mechanisms in acidophilic micro-organisms. Microbiology 2003, 149: 1959-1970.

9. She Q, Singh RK, Confalonieri F, Zivanovic Y, Allard G, Awayez MJ, Chan-Weiher CC-Y, Clausen IG, Curtis BA, De Moors A, Erauso G, Fletcher C, Gordon PM, Heikamp-de Jong I, Jeffries AC, Kozera C], Medina N, Peng X, Thi-Ngoc HP, Redder P, Schenk ME, Theriault C, Tolstrup N, Charlebois RL, Doolittle WF, Duguet M, Gaasterland T, Garrett RA, Ragan MA, Sensen CW, Van der Oost J: The complete genome of the crenarchaeon Sulfolobus solfataricus P2. Proc Natl Acad Sci USA 200I, 98:7835-40.

10. Zillig W, Stetter KO, Wunderl S, Schulz W, Priess H, Scholz I: The Sulfolobus-Caldariella Group - Taxonomy on the Basis of The Structure Of Dna-Dependent Rna-Polymerases. Arch Microbiol 1980, I 25:259-269.

II. Peterson JD, Umayam LA, Dickinson T, Hickey E, White O: The Comprehensive Microbial Resource. Nucleic Acids Res 200I, 29:123-125.

12. Dionne I, Robinson NP, McGeoch AT, Marsh A, Reddish VL, Bell SD: Independent Meeting DNA replication in the hyperthermophilic archaeon Sulfolobus solfataricus. Biochem Soc Trans 2003, 31:674-676.

13. Chong PK, Wright PC: Identification and Characterization of the Sulfolobus solfataricus P2 Proteome. J Proteome Res 2005, 4: $1789-1798$.

14. Barry RC, Young MJ, Stedman KM, Dratz EA: Proteomic mapping of the hyperthermophilic and acidophilic archaeon Sulfolobus solfataricus P2. Electrophoresis 2006, 27:2970-83.

15. Chong PK, Burja AM, Radianingtyas H, Fazeli A, Wright PC: Translational and transcriptional analysis of Sulfolobus solfataricus P2 to provide insights into alcohol and ketone utilisation. Proteomics 2007, 7:424-35.

16. Brouns SJ, Walther J, Snijders AP, van de Werken HJ, Willemen HL, Worm P, de Vos MG, Andersson A, Lundgren M, Mazon HF, van den Heuvel RH, Nilsson P, Salmon L, de Vos WM, Wright PC, Bernander $\mathrm{R}$, van der Oost J: Identification of the missing links in prokaryotic pentose oxidation pathways: evidence for enzyme recruitment. J Biol Chem 2006, 28 I:27378-88.

17. Snijders AP, Walther J, Peter S, Kinnman I, de Vos MG, van de Werken HJ, Brouns SJ, van der Oost J, Wright PC: Reconstruction of central carbon metabolism in Sulfolobus solfataricus using a two-dimensional gel electrophoresis map, stable isotope labelling and DNA microarray analysis. Proteomics 2006, 6:1518-29.

18. Wang $\mathrm{H}$, Hanash $\mathrm{S}$ : Multi-dimensional liquid phase based separations in proteomics. J Chromatogr B Analyt Technol Biomed Life Sci 2003, 787: II-8.

19. Schaefer H, Chervet JP, Bunse C, Joppich C, Meyer HE, Marcus K: A peptide preconcentration approach for nano-high-performance liquid chromatography to diminish memory effects. Proteomics 2004, 4:254I-2544.

20. Abbanat DR, Ferry J: Resolution of Component Proteins in an Enzyme Complex from Methanosarcina thermophila Catalyzing the Synthesis or Cleavage of Acetyl-CoA. Proc Natl Acad Sci USA 1991, 88:3272-32763.

21. Grahame DA: Catalysis of acetyl-CoA cleavage and tetrahydrosarcinapterin methylation by a carbon monoxide dehydrogenase-corrinoid enzyme complex. I Biol Chem 1991, 266:22227-22233.

22. Limauro D, Pedone E, Pirone L, Bartolucci S: Identification and characterization of I-Cys peroxiredoxin from Sulfolobus solfataricus and its involvement in the response to oxidative stress. FEBS / 2006, 273:72I-3I.

23. Kawakami R, Sakuraba H, Kamohara S, Goda S, Kawarabayasi $Y$, Ohshima T: Oxidative Stress Response in an Anaerobic Hyperthermophilic Archaeon: Presence of a Functional Peroxiredoxin in Pyrococcus horikoshii. J Biochem (Tokyo) 2004, 136:54I-547.

24. Hopfner KP, Karcher A, Craig L, Woo TT, Carney JP, Tainer JA: Structural biochemistry and interaction architecture of the DNA double-strand break repair Mre II nuclease and Rad50ATPase. Cell 200I, 105:473-85.

25. Constantinesco F, Forterre P, Elie C: NurA, a novel 5'-3' nuclease gene linked to rad50 and mre II homologs of thermophilic Archaea. EMBO Rep 2002, 3:537-42.
26. Constantinesco F, Forterre P, Koonin EV, Aravind L, Elie C: A bipolar DNA helicase gene, herA, clusters with rad50, mre II and nurA genes in thermophilic archaea. Nucleic Acids Res 2004, 32:1439-47.

27. Manzan A, Pfeiffer G, Hefferin ML, Lang CE, Carney JP, Hopfner KP: MlaA, a hexameric ATPase linked to the Mrel I complex in archaeal genomes. EMBO Rep 2004, 5:54-9.

28. Mittenhuber G: Phylogenetic analyses and comparative genomics of vitamin B6 (pyridoxine) and pyridoxal phosphate biosynthesis pathways. J Mol Microbiol Biotechnol 200I, 3:I-20.

29. Schneider $\mathrm{G}$, Kack $\mathrm{H}$, Lindqvist $\mathrm{Y}$ : The manifold of vitamin B6 dependent enzymes. Structure Fold Des 2000, 8:RI-R6.

30. Drewke C, Klein M, Clade D, Arenz A, Muller R, Leistner E: 4-Ophosphoryl-L-threonine, a substrate of the $\mathrm{pdxC}(\operatorname{ser} C)$ gene product involved in vitamin B6 biosynthesis. FEBS Lett 1996, 390:179-82.

3I. Laber B, Maurer W, Scharf S, Stepusin K, Schmidt FS: Vitamin B6 biosynthesis: formation of pyridoxine 5 '-phosphate from 4(phosphohydroxy)-L-threonine and I-deoxy-Dxylulose-5phosphate by PdxA and PdxJ protein. FEBS Lett 1999, 449:45.

32. Braun EL, Fuge EK, Padilla PA, Werner-Washburne M: A stationaryphase gene in Saccharomyces cerevisiae is a member of a novel, highly conserved gene family. J Bacteriol 1996, I 78:6865-6872

33. Ehrenshaft $M$, Jenns $A E$, Chung KR, Daub ME: SORI, a gene required for photosensitizer and singlet oxygen resistance in Cercospora fungi, is highly conserved in divergent organisms. Mol Cell I998, I:603-609.

34. Spikes JD: Photosensitization. In The Science of Photobiology 2nd edition. Edited by: Smith KC. New York:Plenum Press; 1989:79-I I0.

35. Daub ME, Jenns AE, Ehrenshaft M: Fungal resistance to photosensitizers that generate singlet oxygen. In Light-Activated Pest Control 1995 ACS Symposium Series 616 Edited by: Heitz JR, Downum KR. Washington, D.C.: American Chemical Society:20I-216.

36. Jain SK, Lim G: Pyridoxine and pyridoxamine inhibits superoxide radicals and prevents lipid peroxidation, protein glycosylation, and $(\mathrm{Na}++\mathrm{K}+)$-ATPase activity reduction in high glucose-treated human erythrocytes. Free Radic Biol Med 200I, 30:232-7.

37. Ehrenshaft M, Bilski P, Li MY, Chignell CF, Daub ME: A highly conserved sequence is a novel gene involved in de novo vitamin B6 biosynthesis. Proc Natl Acad Sci USA 1999, 96:9374-93780.

38. Oikawa S, Hiraku Y, Fujiwara T, Saito I, Kawanishi S: Site-specific hydroxylation at polyguanosine in double-stranded DNA by nickel (II) in the presence of SH compounds: comparison with singlet oxygen-induced DNA damage. Chem Res Toxicol 2002, 15:1017-22.

39. Kawanishi S, Inoue S, Yamamoto K: Site-specific DNA damage induced by nickel (II) ion in the presence of hydrogen peroxide. Carcinogenesis 1989, 10:2231-5.

40. Ito T, Chiba T, Ozawa R, Yoshida M, Hattori M, Sakaki Y: A comprehensive two-hybrid analysis to explore the yeast protein interactome. Proc Natl Acad Sci USA 200I, 98:4569-74.

4I. Murayama N, Shimizu H, Takiguchi S, Baba Y, Amino H, Horiuchi T, Sekimizu K, Miki T: Evidence for involvement of Escherichia coli genes pmbA, csrA and a previously unrecognized gene tIdD, in the control of DNA gyrase by letD $(\mathrm{ccdB})$ of sex factor F. J Mol Biol 1996, 256:483-502.

42. Allali N, Afif $H$, Couturier M, Van Melderen L: The highly conserved TIdD and TIdE proteins of Escherichia coli are involved in microcin B 17 processing and in CcdA degradation. J Bacteriol 2002, 184:3224-3I.

43. Valenti A, Napoli A, Ferrara MC, Nadal M, Rossi M, Ciaramella M: Selective degradation of reverse gyrase and DNA fragmentation induced by alkylating agent in the archaeon Sulfolobus solfataricus. Nucleic Acids Res 2006, 34:2098-108.

44. Jo J, Jang YS, Kim KY, Kim MH, Kim IJ, Chung WI: Extension of the Rhizobium meliloti succinoglycan biosynthesis gene cluster: identification of the exs $A$ gene encoding an $A B C$ transporter protein, and the exsB gene, which probably codes for a regulator of succinoglycan biosynthesis. Biochem Biophys Res Commun 1997, 239:835-839.

45. Becker A, Kuster H, Niehaus K, Puhler A: Isolation of ALUI-P gene encoding a protein with aluminum tolerance activity from Arthrobacter viscosus. Mol Gen Genet 1995, 249:487-497. 
46. Asthana RK, Srivastava S, Singh AP, Kayastha AM, Singh SP: Identification of maltooligosyltrehalose synthase and maltooligosyltrehalose trehalohydrolase enzymes catalysing trehalose biosynthesis in Anabaena 7120 exposed to $\mathbf{N a C l}$ stress. J Plant Physiol 2005, 162: 1030-7.

47. Cardoso FS, Castro RF, Borges N, Santos H: Biochemical and genetic characterization of the pathways for trehalose metabolism in Propionibacterium freudenreichii, and their role in stress response. Microbiology 2007, I 53:270-280.

48. Timmins J, Leiros HK, Leonard G, Leiros I, McSweeney S: Crystal structure of maltooligosyltrehalose trehalohydrolase from Deinococcus radiodurans in complex with disaccharides. J Mol Biol 2005, 347:949-63.

49. Skopelitis DS, Paranychianakis NV, Paschalidis KA, Pliakonis ED, Delis ID, Yakoumakis DI, Kouvarakis A, Papadakis AK, Stephanou EG, Roubelakis-Angelakis KA: Abiotic stress generates ROS that signal expression of anionic glutamate dehydrogenases to form glutamate for proline synthesis in tobacco and grapevine. Plant Cell 2006, 1 8:2767-8I.

50. Mulrooney SB, Hausinger RP: Nickel uptake and utilization by microorganisms. FEMS Microbiol Rev 2003, 27:239-6I.

51. Kang BS, Kim YM: Cloning and Molecular Characterization of the Genes for CarbonMonoxide Dehydrogenase and Localization of Molybdopterin, Flavin Adenine Dinucleotide, and Iron-Sulfur Centers in the Enzyme of Hydrogenophaga pseudoflava. J Bacteriol 1999, 181:5581-5590.

52. Wu M, Ren Q, Durkin AS, Daugherty SC, Brinkac LM, Dodson RJ, Madupu R, Sullivan SA, Kolonay JF, Nelson WC, Tallon LJ, Jones KM, Ulrich LE, Gonzalez JM, Zhulin IB, Robb FT, Eisen JA: Life in Hot Carbon Monoxide: The Complete Genome Sequence of Carboxydothermus hydrogenoformans Z-290I. Plos Genetics 2005, I:563-574.

53. Laemmli UK: Cleavage of structural proteins during the assembly of the head of bacteriophage T4. Nature 1970, 227:680-685.

54. O'Farrell PH: High Resolution Two-dimensional Electrophoresis of Proteins. J Biol Chem 1975, 250:4007-402 I.

55. Rocco M, D'Ambrosio C, Arena S, Faurobert M, Scaloni A, Marra M: Proteomic analysis of tomato fruits from two ecotypes during ripening. Proteomics 2006, 6:378I-379I.

56. D'Ambrosio C, Arena S, Fulcoli G, Scheinfeld MH, D'Adamio L, Scaloni A: Hyperphosphorylation of JNK-interacting protein I, a protein associated with Alzheimer disease. Mol Cell Proteomics 2006, 5:97-II3.

57. Perkins DN, Pappin DJ, Creasy DM, Cottrell JS: Probability-based protein identification by searching sequence databases using mass spectrometry data. Electrophoresis 1999, 20:355I-3567.

58. MacCoss MJ, Wu CC, Yates JR 3rd: Measurement of the isotope enrichment of stable isotope-labeled proteins using high-resolution mass spectra of peptides. Anal Chem 2002, 74:5593-5599.

59. NCBI database [ftp://ftp.ncbi.nih.gov/genomes/Bacteria/ Sulfolobus solfataricus/NC 002754.faa]

60. Grogan DW: Phenotypic characterization of the genus Sulfolobus: comparison of five wild-type strains. J Bacteriol 1989, 171:6710-6719.

61. Grogan DW, Palm P, Zillig W: Isolate B 12, which harbours a virus-like particle, represents a new species of the archaebacterial genus Sulfolobus, Sulfolobus shibatae, sp. nov. Arch Microbiol 1990, I 54:594-599.

62. Grogan DW: Evidence that I-Galactosidase of Sulfolobus solfataricus Is Only One of Several Activities of a ThermostableD-Glycosidase. Appl Env Microbiol I991, 57:1644-1649.

63. Merone L, Mandrich L, Rossi M, Manco G: A thermostable phosphotriesterase from the archaeon Sulfolobus solfataricus: cloning, overexpression and properties. Extremophiles 2005, 9:297-305.

64. Pisani FM, De Martino C, Rossi M: A DNA polymerase from the archaeon Sulfolobus solfataricus shows sequence similarity to family B DNA polymerases. Nucleic Acids Res 1992, 20:27 I I-6.

65. Link AJ, Eng J, Schieltz DM, Carmack E, Mize GJ, Morris DR, Garvik $B M$, Yates JR 3rd: Direct analysis of protein complexes using mass spectrometry. Nat Biotechnol 1999, 17:676-682.

66. Peng J, Elias JE, Thoreen CC, Licklider LJ, Gygi SP: Evaluation of multidimensional chromatography coupled with tandem mass spectrometry (LC/LC-MS/MS) for large-scale protein analysis: the yeast proteome. J Proteome Res 2003, 2:43-50.

67. PredictProtein [http://www.expasy.org]

68. Sulfolobus solfataricus P2 [http://www-archbac.u-psud.fr/ projects/sulfolobus/]
Publish with Bio Med Central and every scientist can read your work free of charge

"BioMed Central will be the most significant development for disseminating the results of biomedical research in our lifetime. "

Sir Paul Nurse, Cancer Research UK

Your research papers will be:

- available free of charge to the entire biomedical community

- peer reviewed and published immediately upon acceptance

- cited in PubMed and archived on PubMed Central

- yours - you keep the copyright
BioMedcentral 